\title{
Deadwood in the oak forests of the Left Bank Forest-steppe of Ukraine
}

\author{
Volodymyr Yu. Yarotskiy ${ }^{1}$,Volodymyr P. Pasternak ${ }^{1,2} \bowtie$, Vitalii V. Nazarenko $^{2}$ \\ ${ }^{1}$ Ukrainian Research Institute of Forestry and Forest Melioration named after G.M. Vysotsky, Department of Forest \\ Monitoring and Certification, Pushkinska 86, 61024, Kharkiv, Ukraine, e-mail: Pasternak65@ukr.net \\ ${ }^{2}$ Kharkiv National Agrarian University, Faculty of Forestry, Department of Forest Management, Forest Exploitation \\ and Life Safety, 62483, Kharkiv region, Kharkiv district, „Dokuchaevske - 2”, Kharkiv, Ukraine
}

\begin{abstract}
Deadwood is an important component of forest ecosystems, and difference in the deadwood carbon stock depends on many variables including forest management. The aim of our study was to determine the patterns of formation of deadwood stocks in oak (Quercus robur L.) forests in the Left Bank Forest-steppe of Ukraine. As an outcome of the research, the data on deadwood parameters were obtained. The growth characteristics and coarse woody debris (CWD) characteristics were measured on intensive monitoring and inventory plots. Assessment of morphometric parameters of the CWD in oak stands was carried out by measuring diameters at top and bottom cut and length; to determine the carbon content, deadwood density was used. The distribution of deadwood by tree species, sizes and stages of decomposition was defined. The stock of dead trees (snags) in oak forest is $15.2 \mathrm{~m}^{3} / \mathrm{ha}$ and that of logs is $21.5 \mathrm{~m}^{3} / \mathrm{h}$. The carbon accumulation in oak forest stands in the Left Bank Forest-steppe of Ukraine was 3.4 and $4.5 \mathrm{t} \mathrm{C} / \mathrm{ha}$ in dead trees and logs, respectively. The dynamics of deadwood stocks according to the results of repeated observations was given.
\end{abstract}

\section{KeY WORDS}

coarse woody debris, dead trees (snags), dead logs, growing stock, stand

\section{INTRODUCTION}

Deadwood is an important structural component of the forest ecosystems and plays a key role in many aspects of their functioning, influencing biological, physical and geochemical processes (Harmon et al. 1986). The most important functions of the deadwood in natural forest ecosystems include the following: environmentforming; maintaining and regulatory; habitat stabilisation and protective (Izhyk 2013). In particular, it is a major habitat for invertebrates, hollow-nesting birds, mosses, xylotrophic fungi and other organisms. With deadwood decomposition, especially favourable conditions are created for the development of ground vegetation and renewal of forest tree species (Smit et al. 2012; Chećko et al. 2015). After the mortmass humification, it becomes an important component of the forest soils. The deadwood is also important for the continued accumulation of carbon and soil protection against erosion. Of the total carbon content in forests, about $15 \%$ is lo- 
cated in deadwood. Deadwood is an important component of forest stands at carbon sequestration evaluation based on the recommendations of the Intergovernmental Panel on Climate change (IPCC 2014, 2013).

In Ukraine, as in some other European countries, the deadwood is usually removed from the forest for consumer needs, to prevent fire, forest pest and diseases spread. However, the use of deadwood is not always economically efficient, in addition, its complete removal leads to a decrease in the level of biodiversity, carbon stocks, depletion of soils, etc. (Bilous et al. 2019). Now the crucial role of deadwood as essential element of forest ecosystem is confirmed by the scientific community. According to Skrylnyk (2015) and Meshkova (2018) research, removal of dead wood would be inappropriate, especially where it is economically unprofitable. As a source of xylophagous insect pests, it is usually no longer a threat for living trees.

Deadwood includes the following components (Hagemann et al. 2009): standing dead trees (snags), lying dead logs, twigs and stumps. Coarse woody debris (CWD) includes standing snags, logs, chunks of wood and large branches (Harmon et al. 1986). The volume of deadwood is one of the Pan-European indicators of sustainable forest management. According to the estimation of the state of Europe's forests in 2010, the weighted average volume of total deadwood as the sum of both dead trees and lying deadwood is about $11.5 \mathrm{~m}^{3} /$ ha for the reporting countries and deadwood amounts range from $8 \mathrm{~m}^{3} / \mathrm{ha}$ in North Europe to $20 \mathrm{~m}^{3} / \mathrm{ha}$ in Central-West Europe (Global Forest Resources Assessment 2015). In Ukraine, the average stock of deadwood is $6 \mathrm{~m}^{3} / \mathrm{ha}\left(3.7 \mathrm{~m}^{3} / \mathrm{ha}\right.$ for standing deadwood trees and $2.3 \mathrm{~m}^{3} /$ ha for lying deadwood). According to Shvidenko et al. (2014), stock of snags and dead logs in oak forests for the Forest-Steppe zone of Ukraine were amounted to 30.2 and 22.9 million $\mathrm{m}^{3}$, respectively. The amount of deadwood, particularly dead trees, has increased slightly in most of the Europe's regions for the past 20 years. In Central-Eastern Europe, it is about $7 \mathrm{~m}^{3} /$ ha and has a tendency to decrease compared to that in 1990, unlike other regions. The amount of deadwood varies considerably between vegetation zones and forest site conditions and is influenced by forest management regimes.

The stock of deadwood and its dynamics depend on the growing stock and origin of the stands, tree species composition and age. The stock of dead wood, even within a homogeneous stand, can vary greatly (Pasternak and Yarotskiy 2010). The features of deadwood formation in oak stands in different objects have been researched by Bobiec (2002), Nordén (2004), Smit et al. (2012), Pyvovar et al. (2016), Bilous et al. (2017, 2019) and others. The natural forests recovering from natural or anthropogenic disturbances are characterised by the U-shaped form of CWD accumulation, whereas in forest plantations, the initial reserves of detritus are usually small, and its growth corresponds to the J-shaped curve (Shvidenko et al. 2009).

According to Matsala and Bilous (2017), in Ukraine, the average proportion of dead trees and logs volumes to growing stock (for areas where these kinds of deadwood were found) is evaluated as about $6.1 \%$ and $5.4 \%$, respectively. The carbon density per area is about $0.27 \mathrm{~kg} \mathrm{C} / \mathrm{m}^{2}$ for snags and $0.24 \mathrm{~kg} \mathrm{C} / \mathrm{m}^{2}$ for logs. It was found that the carbon density of snags increases with the increase in soil moisture and the carbon density of logs increases in areas with lower soil fertility. In general, snags and logs of oak stand in Ukraine deposit $830 \mathrm{Gg} \mathrm{C}$ and $227 \mathrm{Gg} \mathrm{C}$, respectively, which in sum is about only $0.8 \%$ of the total potential biomass carbon sink in all oak Ukrainian forests. The results indicate the insignificant role of coarse woody debris in carbon depositing processes in Ukrainian oak forests in comparison with the oak stands in other European countries.

According to Bilous et al. (2019), CWD is insufficiently accounted in forest-stand-wise inventory data and have estimated potential of this compartment to store $4.5 \%$ of total oak stand biomass $\mathrm{C}$ according to empirical data. Mean dead biomass $\mathrm{C}$ stock (CWD and fine litter together) is nearly $9.3 \%$ of total biomass stock. Modelling of oak dead logs decomposition indicates that deadwood may remain in ecosystem for decades, achieving $40-50 \mathrm{~kg} / \mathrm{m}^{-3}$ wood density at 100 years point after tree death, thus playing substantial role not only as habitat for species, but also as $\mathrm{C}$ sink in mid-term perspective.

Some studies on the CWD in oak stands were conducted in Poland. For example, Smit et al. (1999) analysed the oak regeneration concerning CWD in the Białowieża National Park. This study shows that CWD plays an essential role in the oak regeneration in old- 
growth temperate forest ecosystems, predominantly via protection against ungulate browsing. Sanitary cutting of infested trees, common management practice in temperate forests, prevents the natural accumulation of CWD and so can be counter-productive for the regeneration of appreciated species. Chećko et al. (2015) stressed the importance of constant presence of deadwood, to ensure the diversity of this substrate and to allow the natural dynamics of deadwood-dependent species populations.

According to the data on 01 January 2011, the area of land covered with forest vegetation in the Left Bank Forest-steppe of Ukraine is 612,000 ha and oak forests occupy $46.4 \%$. Oak forests perform important ecological, social and economic functions. From this point of view, it is of considerable interest to conduct studies on the carbon sequestration in the deadwood of Oak stands in the Left Bank Forest-steppe of Ukraine.

In this regard, the purpose of our study was to determine the patterns of deadwood formation and to evaluate carbon stocks in it. To achieve this goal, the following tasks were set: measuring the morphometric parameters of deadwood in oak stands; calculation of the mortmass stock based on the tested method; and calculation of carbon content per 1 ha of stands.

\section{Material AND MEthods}

The studies were carried out in the oak forest stands of the Left Bank Forest-steppe of Ukraine. The research area is characterised by a temperate continental climate. The average annual precipitation is $500-525 \mathrm{~mm}$, and in the warm season, it is $350-375 \mathrm{~mm}$. Absolute maximum temperatures are in July-August $\left(+39^{\circ} \mathrm{C}\right)$; the relative humidity during the vegetation period fluctuates from $48 \%$ to $87 \%$ and may drop to $30 \%$. The objects of research were the Oak (Quercus robur L.) stands.

Specific features of the structure and dynamics of deadwood in the forests of the Left-Bank Forest-

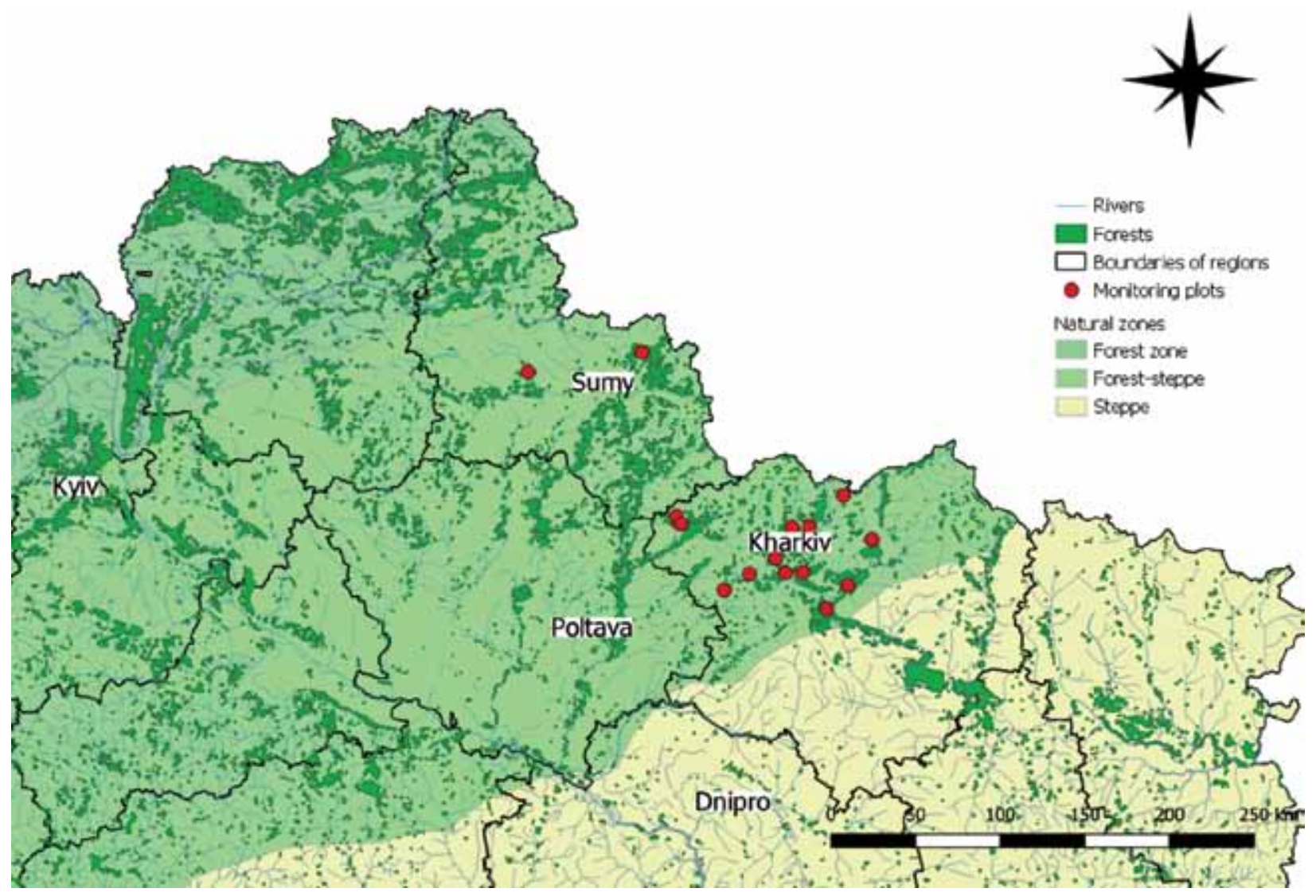

Figure 1 Monitoring plots in oak forests in the Left Bank Forest-steppe of Ukraine 
steppe of Ukraine were studied on 28 monitoring plots located at national parks 'Gomilshansky forests' and 'Slobozhansky', as well as in State Forestry Enterprises. Repeat observations were performed on 15 intensive monitoring plots (Fig. 1).

On all sample plots of fixed area mapping and measuring of trees, the description of the undergrowth and ground vegetation, soils and deadwood was carried out. For each unit of dead logs, species, sizes (largest and smallest diameters, length), decomposition stage, decay type and exposition were determined (Pyvovar et al. 2016). By the decomposition (destruction) stage, the dead trees and logs were divided into 5 classes (Travaglini and Chirici 2006; Bilous 2014). The threshold of minimal diameter for live and dead trees was $8 \mathrm{~cm}$, for dead logs is $7 \mathrm{~cm}$ and for stumps is $10 \mathrm{~cm}$. The mortmass of dead logs was calculated based on the data on the diameters at top and bottom cut and length. Fine woody debris $(\mathrm{d}>1 \mathrm{~cm})$ was estimated in percent from the plot area and proportion of the dead logs stock. The diameter and height were measured for the stumps.

For the calculation of carbon stocks in the dead trees and dead logs, indicators of the basic density of deadwood in terms of decomposition stage and carbon content were used (Pasternak and Yarotskiy 2010). The taxation indicators were calculated by methods commonly used in taxation.
Statistical analysis was performed using the Statistical Package Excel and Statistika for correlation between the basic taxation parameters.

\section{Results}

During the years 2010-2014, the measurements of morphometric parameters for stands at 28 plots were carried out (Tab. 1).

The research data adequately represent the oak forests of the studied area by tree species composition and productivity. A significant correlation is established only between the dead logs' stock and the age of the tree stand $(r=0.61)$. Between the stock of snags and other indicators of the forest stands, the correlation relationship was at the level of 0.1 .

Dead wood was found in forest stands of all age groups and forest site conditions (Tab. 2).

According to the results of the assessment at monitoring plots, the presence of deadwood is registered in 5 types of forest site condition. By the proportion of dead trees' amount and stocks, the highest level of dead trees was observed in wet relatively rich condition $\left(\mathrm{C}_{3}\right.$, $101-120$ year) and rich fresh condition $\left(D_{2}, 121-140\right.$ year).

As shown in Table 2, the total stock of deadwood in oak stands, on an average, is $36.7 \mathrm{~m}^{3} /$ ha and varied from 1.5 to $105.3 \mathrm{~m}^{3} / \mathrm{ha}$. The proportion of dead tree stock is $51.0 \%$ of total deadwood. The average share of

Table 1. Forestry growth characteristics of oak stands

\begin{tabular}{|c|c|l|c|c|c|c|}
\hline Age (years) & $\begin{array}{c}\text { Number } \\
\text { of plots }\end{array}$ & \multicolumn{1}{|c|}{ Tree species composition } & $\begin{array}{c}\text { Forest site } \\
\text { condition }\end{array}$ & Site index & $\begin{array}{c}\text { Relative density } \\
\text { of stocking }\end{array}$ & $\begin{array}{c}\text { Growing stock } \\
\left(\mathrm{m}^{3} / \text { ha }\right)\end{array}$ \\
\hline $41-60$ & 1 & 9QR1PT+TC & $\mathrm{D}_{2}$ & Ia & 0.74 & 254 \\
\hline $61-80$ & 4 & 8QR1TC1AP+FE,AC,UG & $\mathrm{D}_{2}$ & II & 0.78 & 297 \\
\hline $61-80$ & 1 & 9QR1FE+UG, AC & $\mathrm{C}_{2}$ & I & 0.69 & 222 \\
\hline $81-100$ & 1 & 10QR+AC,AP,FE,UG & $\mathrm{D}_{1}$ & III & 0.76 & 252 \\
\hline $81-100$ & 8 & 7QR1FE1AP1TC+AC,UG & $\mathrm{D}_{2}$ & II & 0.80 & 310 \\
\hline $81-100$ & 1 & 7QR3PS & $\mathrm{C}_{2}$ & II & 0.89 & 402 \\
\hline $101-120$ & 1 & 4QR4FE1BP1AP+PT & $\mathrm{C}_{3}$ & II & 0.82 & 296 \\
\hline $101-120$ & 7 & 6QR1FE1AC1TC1AP+UG,PT & $\mathrm{D}_{2}$ & II & 0.84 & 345 \\
\hline $101-120$ & 2 & 7QR1FE1AG1AP+TC,AC,UG & $\mathrm{D}_{3}$ & II & 0.91 & 393 \\
\hline $121-140$ & 2 & 5QR2FE2AP1TC & $\mathrm{D}_{2}$ & II & 0.87 & 363 \\
\hline
\end{tabular}

QR, Quercus robur L.; PT, Populus tremula L.; TC, Tilia cordata Mill.; AP, Acer platanoides L.; AC, Acer campestre L.; FE, Fraxinus excelsior L.; UG, Ulmus glabra Huds.; BP, Betula pendula Roth.; AG, Alnus glutinosa (L.) Gaerth.; PS, Pinus sylvestris L.; $\mathrm{C}_{2}$, fresh relatively rich condition; $\mathrm{C}_{3}$, moist relatively rich condition; $\mathrm{D}_{1}$, dry rich condition; $\mathrm{D}_{2}$, fresh rich condition; $\mathrm{D}_{3}$, moist rich condition. 
Table 2. Average deadwood stock

\begin{tabular}{|c|c|c|c|c|c|}
\hline Age (years) & $\begin{array}{c}\text { Number } \\
\text { of plots }\end{array}$ & $\begin{array}{c}\text { Dead trees } \\
\left(\mathrm{m}^{3} / \mathrm{ha}\right)\end{array}$ & $\begin{array}{c}\text { Dead logs } \\
\left(\mathrm{m}^{3} / \mathrm{ha}\right)\end{array}$ & $\begin{array}{c}\text { Total } \\
\left(\mathrm{m}^{3} / \mathrm{ha}\right)\end{array}$ & $\begin{array}{c}\text { Proportion from growing stock } \\
(\%)\end{array}$ \\
\hline $41-60$ & 1 & 1.5 & 0.0 & 1.5 & 0.6 \\
\hline $61-80$ & 4 & 10.7 & 7.7 & 18.4 & 6.2 \\
\hline $61-80$ & 1 & 24.8 & 12.1 & 36.9 & 5.6 \\
\hline $81-100$ & 1 & 12.5 & 1.5 & 14.0 & 6.3 \\
\hline $81-100$ & 8 & 11.5 & 8.0 & 19.5 & 9.2 \\
\hline $81-100$ & 1 & 20.1 & 16.7 & 36.8 & 35.6 \\
\hline $101-120$ & 1 & 43.0 & 62.3 & 105.3 & 14.2 \\
\hline $101-120$ & 7 & 14.1 & 34.9 & 49.0 & 10.8 \\
\hline $101-120$ & 2 & 27.5 & 15.1 & 42.6 & 24.2 \\
\hline $121-140$ & 2 & 17.9 & 70.1 & 88.0 & $11.7 \pm 11.4$ \\
\hline Average & 28 & $15.2 \pm 13.8$ & $21.5 \pm 25.6$ & $36 \pm 34.4$ & $7.5-15.9$ \\
\hline Confidence interval & & $10.1-20.3$ & $12.0-31.0$ & $8.7-34.3$ & \\
\hline
\end{tabular}

deadwood from growing stock is $13.3 \%$. The maximum share of deadwood is noted in mature and overmature forest stands. This can be explained by the predominance of coppice oak trees in this age group of stands and deterioration of stands condition.

For dead logs, the average stock of mortmass is $9.1 \mathrm{t} / \mathrm{ha}$ and the average stock of carbon is 4.5 ton per ha, and for dead tree, these are 6.8 and $3.4 \mathrm{t} / \mathrm{ha}$, respectively. The coverage of fine woody debris (twigs), on an average, at monitoring plots is $6.0 \%(4.8-7.2 \%)$; the share of the stock from dead logs is $7.5 \%$. The average stock of stumps is $1.1 \mathrm{~m}^{3} / \mathrm{ha}$.

According to our observations, the formation of a large volume of deadwood has a focal character. This occurs during the massive fall of trees as a result of windbreaks, dying because of diseases, ageing and so on. Typically, these are local processes that occupy certain areas with clearly defined boundaries.

The variety of deadwood by species is quite high; in total, it is presented by 8 tree species: from 5 species on 2 plots to 1 species on 10 plots. In dead trees, oak predominates $(69.3 \%)$; the share of maples is $14.2 \%$, aspen is $7.0 \%$ and lime is $6.3 \%$. In dead logs, the largest proportion is oak $60.2 \%$; the share of ash is $14.0 \%$, maples is $9.6 \%$, lime is $6.9 \%$ and that of other tree species is less than $5 \%$. This explained not only the dominance of the oak in the stands but also significant mortality of oak in comparison with other species and longer decomposition period.
The average (mean) stage of decomposition for oak is 2.3 , for ash is 1.2 , for maple is 1.9 , for aspen is 1.4 , for alder is 2.2 and for lime is 2.6. The distribution of dead logs' stock according to the decomposition stages is shown in Figure 2.

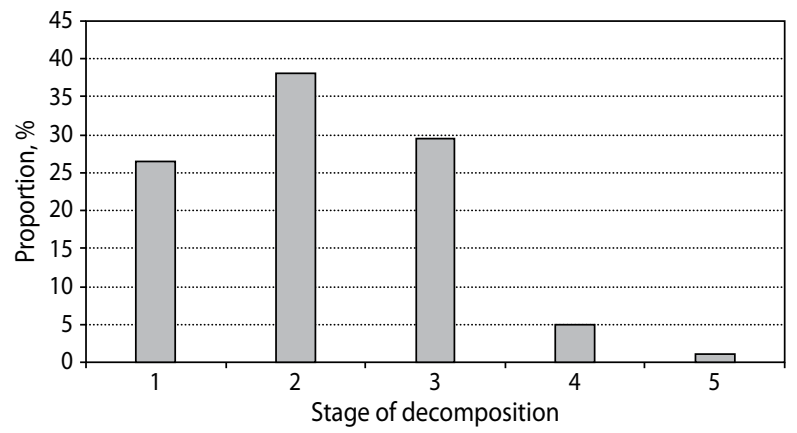

Figure. 2 Distribution of dead logs by stages of decomposition

Dimensions of deadwood are important in relation to ecological function of deadwood and the intensity of its decomposition. The largest average diameter was fixed for ash $(25.8 \mathrm{~cm})$; slightly less for oak and Norway maple $(18.2 \mathrm{~cm})$ and lime (16.1); and least for field maple $(11.5 \mathrm{~cm})$. The largest proportion was occupied by logs with an average diameter of 10.1-20 cm (23.7\%) and 20.1-30 cm (23.8\%) (Fig. 3).

The results of observations from 2011-2014 (1 cycle) to 2015-2018 (2 cycle) on monitoring 


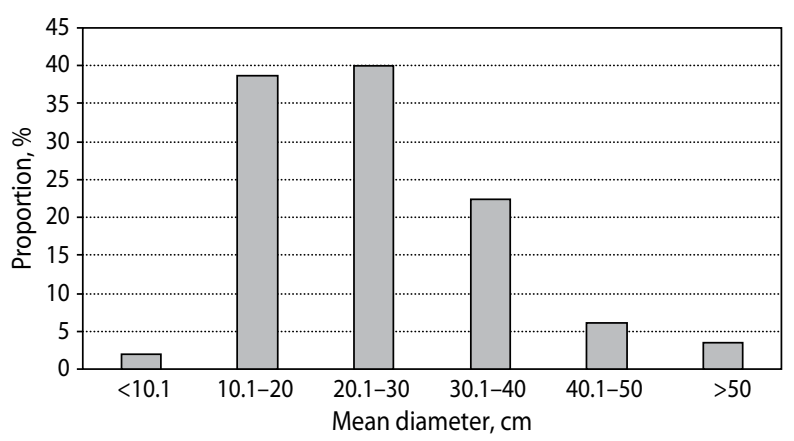

Figure. 3 Distribution of dead logs by mean diameter

plots (Tab. 3) show that the stage of formation and accumulation of deadwood changes with the stage of active decomposition or removal.

During the monitoring period, both quantitative and qualitative changes in the deadwood took place at the monitoring plots. Data analysis shows that there was an increase in the stock of deadwood mainly because of dead logs. Considerable loss of deadwood occurred at the plots N3 as a result of the removal of deadwood from the forest area during the sanitary felling.

\section{Discussion}

At present, there is no scientific justification for how much deadwood should be left in commercial forests. However, with a low level of deadwood, even a small increase in its amount is significantly reflected in the growth of biodiversity. The optimal stock of deadwood per unit area will vary considerably depending on the forest site conditions, the growing stock, the forest category, the natural zone, the age of the tree stand and so on. In our opinion, the definition of the amount of dead wood sufficient for the implementation of ecosystem functions of the forest and forest management for different forest site conditions is one of the important tasks. At the same time, only stock per area cannot provide a complete and objective picture of the ecological processes occurring in the forest. A more objective and meaningful indicator is the structure of the deadwood of the forest area: the distribution of the dead logs and dead trees by the decomposition stages, taking into account their size and placement.

Table 3. Dynamic of dead wood stock on monitoring plots $\left(\mathrm{m}^{3} / \mathrm{ha}\right)$

\begin{tabular}{|c|c|c|c|c|c|c|c|c|}
\hline \multirow{2}{*}{ Number of plots } & \multirow{2}{*}{$\begin{array}{c}\text { Number } \\
\text { of tree species } \\
\text { in deadwood }\end{array}$} & \multicolumn{2}{|c|}{ Dead trees } & \multicolumn{2}{|c|}{ Dead logs } & \multicolumn{2}{|c|}{ Total } & \multirow{2}{*}{ Difference } \\
\hline & & 1 & 2 & 1 & 2 & 1 & 2 & \\
\hline 1 & 1 & 5.3 & 2.7 & 0.1 & 1.1 & 5.4 & 3.8 & -1.6 \\
\hline 2 & 2 & 1.4 & 0.6 & 0.2 & 0.5 & 1.6 & 1.1 & -0.5 \\
\hline 3 & 1 & 12.4 & 2.8 & 19.4 & 6.2 & 31.8 & 9.0 & -22.8 \\
\hline 4 & 2 & 25.1 & 23.8 & 11.2 & 12.0 & 36.3 & 35.8 & -0.5 \\
\hline 5 & 3 & 5.5 & 5.5 & 4.0 & 3.6 & 9.5 & 9.1 & -0.4 \\
\hline 6 & 1 & 24.8 & 9.7 & 12.1 & 33.7 & 36.8 & 43.4 & 6.6 \\
\hline 7 & 4 & 1.9 & 11.8 & 6.1 & 3.8 & 8.0 & 15.6 & 7.6 \\
\hline 8 & 2 & 1.3 & 1.3 & 15.9 & 15.6 & 17.3 & 16.9 & -0.4 \\
\hline 9 & 3 & 0 & 0 & 68.9 & 65.4 & 68.9 & 65.4 & -3.5 \\
\hline 10 & 5 & 13.2 & 18.1 & 90.1 & 87.0 & 103.3 & 105.1 & 1.8 \\
\hline 11 & 0 & 0.0 & 0.0 & 0.0 & 0.0 & 0.0 & 0.0 & 0.0 \\
\hline 12 & 3 & 22.6 & 11.3 & 50.1 & 69.9 & 72.7 & 81.2 & 8.5 \\
\hline 13 & 3 & 8.8 & 27.6 & 2.1 & 2.7 & 10.9 & 30.3 & 19.4 \\
\hline 14 & 4 & 0.0 & 2.6 & 9.0 & 9.9 & 9.0 & 12.5 & 3.5 \\
\hline 15 & 2 & 1.5 & 16.9 & 0.0 & 2.9 & 1.5 & 19.8 & 18.3 \\
\hline Mean & 2.4 & 8.3 & 9.0 & 19.3 & 21.0 & 27.5 & 29.9 & 2.4 \\
\hline Standard deviation & - & 9.3 & 9.1 & 27.8 & 29.1 & 31.3 & 31.4 & 9.8 \\
\hline
\end{tabular}


Compared with the data for Ukraine, presented in the work of Matsala and Bilous (2017) based on the stand-wise forest inventory, the carbon stocks in the oak forests of the Left-Bank Forest-steppe of Ukraine according to our data are slightly bigger for snags and are almost doubled more for CWD. This can be explained in particular by the fact that snags and logs during the stand-wise forest inventory were considered only in those stands where its volume exceeded $5 \mathrm{~m}^{3} /$ ha.

According to data of the state forest inventory enterprise 'Ukrderzhlisproekt' on 01 January 2011, the stock of dead tree in oak forests of Ukraine is $10.7 \mathrm{~m}^{3} /$ ha and logs is $8.9 \mathrm{~m}^{3} / \mathrm{ha}$, which is less than our data, almost on $30 \%$ for dead trees and on $60 \%$ for logs. The difference in estimates, in addition to the threshold, is influenced by the fact that a significant proportion of oak forests in the Left Bank Forest-steppe of Ukraine are classified as nature protection, recreational and protective, where there are restrictions on forest management measures. According to Shvidenko et al. (2009), carbon stock in a temperate forest of Russia is $3.68 \mathrm{t} \mathrm{C}$ /ha for snags and $3.16 \mathrm{t} \mathrm{C} /$ ha for logs, which is similar to our data for snags and on $30 \%$ less for logs.

Dead logs usually decompose faster than dead trees, which is associated primarily with higher soil humidity and more intensive level of biodestruction. The size of the dead logs has a rather high level of diversity, but the proportion of large logs (more than $40 \mathrm{~cm}$ ), which are particularly important for biodiversity conservation (Bölöni et al. 2017), is not high (8.6\%).

\section{Conclusion}

The average CWD stock is $36.7 \mathrm{~m}^{3} /$ ha, including dead trees (snags), $15.2 \mathrm{~m}^{3} / \mathrm{ha}$, dead logs, $21.5 \mathrm{~m}^{3} / \mathrm{ha}$; fine woody debris (twigs), $1.6 \mathrm{~m}^{3} / \mathrm{ha}$; stumps, $1.1 \mathrm{~m}^{3} / \mathrm{ha}$. Thus, the carbon accumulation in oak forest stands in the Left Bank Forest-steppe of Ukraine was $3.4 \mathrm{t} \mathrm{C} /$ ha in dead trees and $4.5 \mathrm{t} \mathrm{C/ha} \mathrm{in} \mathrm{dead} \mathrm{logs.} \mathrm{The} \mathrm{maximum}$ share of deadwood is observed in mature and overmature forest stands. In CWD, the largest proportion is oak (more than 60\%). It is important to conduct a national forest inventory, which allows obtaining objective characteristics of deadwood at the national level, because forest-stand-wise inventory does not provide objective data on dead wood.
The processes of formation and decomposition of deadwood occur cyclically, and following a certain stage of the cycle, one process dominates the other. There was an increase in the stock of deadwood on $2.4 \mathrm{~m}^{3} / \mathrm{ha}$ mainly because of dead logs; however, both the accumulation and removal of deadwood are observed in the monitoring plots.

\section{References}

Bilous, A. 2014. Method of forest dead biomass research (in Ukrainian with English summary). Biological Resources and Nature Management. 6 (3/4), 134-145.

Bilous, A., Matyashuk, R., Bilous, S., Volodymyrenko, V., Matsala, M. 2017. Dynamics of carbon biomass in forest ecosystems of the monumental park of landscape art of nation-wide importance "Feofaniya". Forestryand gardening. http:/journals. nubip.edu.ua/index.php/Lis/article/.../9159/8553

Bilous, A., Matsala, M., Radchenko, V., Matiashuk, R., Boyko, S., Bilous S. 2019. Coarse woody debris in mature oak stands of Ukraine: carbon stock and decomposition features. Forestry Ideas, 25 (1), 196-219.

Bobiec, A. 2002. Living stands and dead wood in the Białowieża suggestions for restoration management. Forest Ecology and Management, 165, 125-140. DOI: $10.1016 / \mathrm{S} 0378-1127(01) 00655-7$

Bölöni, J., Ódor, P., Ádám, R., Scott Keeton, W., Aszalós, R. 2017. Quantity and dynamics of dead wood in managed and unmanaged dry-mesic oak forests in the Hungarian Carpathians. Forest Ecology and Management, 399,120-131. DOI: 10.1016/j.foreco.2017.05.029

Chećko, E., Jaroszewicz, B., Olejniczak, K., Kwiatkowska-Falińska, A.J. 2015. The importance of coarse woody debris for vascular plants in temperate mixed deciduous forests. Canadian Journal of Forest Research, 45 (9), 1154-1163. https://doi.org/10.1139/cjfr-2014-0473

Humphrey J.W., Sippola A.L., Lemperiere G., Dodelin B., Alexander K.N.A. Butler J.E. 2004. Deadwood as an indicator of biodiversity in European forests: from theory to operational guidance. $E F I$ Proceedings, 51, 193-206. 
Hagemann, U., Moronic, M.T., Makeschin, F. 2009. Deadwood abundance in Labrador high-boreal black spruce forests. Canadian Journal of Forest Research, 39, 131-142.

Harmon, M.E. et al. 1986. Ecology of coarse woody debris in temperate ecosystems. Advances in Ecological Research, 15, 133-302. https://doi.org/10.1016/ S0065-2504(08)60121-X

Global Forest Resources Assessment. 2015. Available at https://foresteurope.org/state-europes-forests2015-report/

IPCC. 2014, 2013 Revised Supplementary Methods and Good Practice Guidance Arising from the Kyoto Protocol (eds.: T. Hiraishi et al.). Published: IPCC, Switzerland. Available at https://www.ipcc-nggip. iges.or.jp/public/kpsg/index.html

Izhyk, H.V. 2013. Role and functions of dead wood in beech virgin forests (in Ukrainian with English summary). Scientific Bulletin of UNFU, 23 (9), 352-357.

Matsala, M.S., Bilous, A.M. 2017. Assessment carbon in coarse woody debris of oak forests in Ukraine (in Ukrainian with English summary). Scientific Bulletin of UNFU, 27 (6), 16-19. https://doi. org $/ 10.15421 / 402706002$

Meshkova, V.L. 2018. Achievements and problems of forest entomology in Ukraine. The Kharkov Entomological Society Gazette, 26 (1), 119-129.

Nordén, B., Götmark, Fr., Tönnberg, M., Ryberg, M. 2004. Dead wood in semi-natural temperate broadleaved woodland: contribution of coarse and fine dead wood, attached dead wood and stumps. Forest Ecology and Management, 194, 234-248. DOI: 10.1016/S0378-1127(04)00186-0
Pasternak, V.P.. Yarotskiy, V.Yu. 2010. Stocks and dynamics of dead wood in the forests of the north-east of Ukraine (in Ukrainian with English summary). Scientific Bulletin of the NULES of Ukraine, 152 (2), 93-100.

Pyvovar, T.S., Pasternak, V.P., Yarotskiy, V.Yu., Buksha, M.I. 2016. State and productivity of oak stands in forest-steppe of Kharkiv region (in Ukrainian with English summary) Forestry and Forest Melioration, 128, 57-62.

Shvidenko, A.Z., Schepaschenko, D.G., Nilsson, S. 2009. Assessment of woody detritus in forests of Russia (in Russian). Forest taxation and management, 1 (41), 133-147.

Shvydenko, A., Lakyda, P., Shchepashchenko, D., Vasylyshyn, R., Marchuk, Y. 2014. Carbon, climate and land management in Ukraine: forest sector. Korsun-Shevchenkivskyi, FOP Gavryshchenko.

Skrylnyk, Ju. Je. 2015. Harmfulness of stem-insects in pine plantations of the Left-Bank Forest-steppe of Ukraine: PhD abstract. (in Ukrainian with English summary). Kharkiv.

Smit, Ch., Kuijper, D.P.J., Prentice, D., Wassen, M.J., Cromsigt J.P. 2012. Coarse woody debris facilitates oak recruitment in Białowieża Primeval Forest, Poland. Forest Ecology and Management, 284, 133-141. https://doi.org/10.1016/j.foreco.2012.07.052

Travaglini, D., Chirici, Gh. 2006. ForestBIOTA project. Forest Biodiversity Test-phase Assessments. Deadwood assessment. Work report. Available at http:// www.forestbiota.org/docs/report_DEADWOOD. pdf 